\title{
The influence of tourism experience self-congruity on the use of virtual social networks
}

\author{
Gonzalo Luna Cortés ${ }^{1,2 *}$
}

Received: 27/04/2016 Accepted: 07/09/2016

\footnotetext{
${ }^{1} \mathrm{PhD}$ student at Universidad de Sevilla, Av. San Francisco Javier, s/n, 41018 Sevilla, Spain.

2 Professor at Konrad Korenz Institution of Higher Education, Cra. 9 Bis \#62-43, Bogota (Colombia); Tel: +573223687280, e-mail: Lunacortes1984@hotmail.com

* Corresponding author
}

\begin{abstract}
Based on previous research in the literature of symbolic consumption and social media, the present study analyses the relationship between tourism experience self-congruity, perceived social value and tourists' use of virtual social networks. The study presents a series of hypotheses and an empirical model, which establishes the relationship between these constructs. In order to contrast the hypotheses, a quantitative research was carried out in the city of Valencia (Spain), using a structured survey and personal interviews. During the analysis of the results, the reliability and the validity of the scales used to measure the constructs were verified by confirmatory factor analysis (CFA). Subsequently, the methodology of the structural equation models (SEM) was used to estimate the relation between the constructs. The results show that tourists perceive higher social value when they live a tourism experience that is congruent with their self-concepts and, when tourists perceive higher social value, the revisit intention increases. When it comes to virtual social networks, experience self-congruity and perceived social value influence their use. Finally, the use of social networks also increases the perceived social value of the experience.
\end{abstract}

(C) 2017 Varna University of Management. All rights reserved

Keywords: symbolic consumption, self-congruity, digital social networks, social value, revisit intention.

Citation: Luna-Cortés, G. (2017) The influence of tourism experience self-congruity on the use of virtual social networks. European Journal of Tourism Research 16, pp. 154-176

\section{Introduction}

Symbolic consumption has been analysed from different perspectives since the 1980s. Most of the research have focused on two variables in order to define this construct: consumer identity and the meaning of products in society (Belk, 1984; Clammer, 1992; Csikszentmihalyi and Rochberg-Halton, 1981; Dittmar, 1992; Edson and Bettman, 2005; Fenollar and Ruiz, 2006; Ger and Belk, 1996; Landon, 1974; Lee, 2013; Lorenzi, 1991; McCracken, 1987; Park et al., 2010; Sun et al., 2014). In this context of analysis, researchers have traditionally studied the symbolism of tangible objects (Belk, 1984; Clammer, 1992; Dittmar 1992; Fenollar and Ruíz, 2006; Ger and Belk, 1996; Landon, 1974; 
Lorenzi, 1991). However, several studies have examined symbolic consumption in the area of tourism in the past few years (e. g. Chen, Leask and Phou, 2016; Kim and Jang, 2014; Kim and Jun, 2016; Kumar and Nayak , 2014; Servidio, 2015; Sharma and Shruti, 2015; Uchiyama and Kohsaka, 2016), and it can be observed that self-congruity is an important construct related to the symbolic consumption of tourism products and services (Ekinci, Sirakaya and Preciado, 2013; Nam, Ekinci and Whyatt, 2011; Chen, Leask and Phou, 2016).

Self-congruity is defined as the matching of the product's image with the consumer's selfconcept (Sirgy, 1982). The studies of this construct in the tourism literature can be divided into two different fields of research: (1) self-congruity and pre-trip decision making (e. g. Ahn, Ekinci and Li, 2011; Beerli, Díaz and Moreno, 2007; Litvin and Goh, 2002; Souza, 2015); and (2) self-congruity and post-trip travel intentions (e. g. Bosnjak et al., 2011; Kastenholz, 2004; Matzler et al., 2016). This paper focuses on self-congruity and post-trip behavioural intentions.

When it comes to post-trip consumer behaviour, some authors have recently pointed out the importance of the used of social media by tourists after their trips (e. g. Amaro, Duarte and Enriques, 2016; Correia, Kozak and Reis, 2014; Kim, Lee and Bonn, 2016; Nadkarni and Hofmann, 2012; Seidman, 2013). It has also been mentioned in the literature the need of research in this area, since "the research on the analysis of virtual social networks in tourism is now in its beginnings" (Hudson et al., 2015, p. 70) and "there is a need of analysis to examine the impact of virtual social networks in tourism" (Zeng and Gerritsen, 2014, p. 34).

There are several reasons that explain the use of social media by tourists during and after their trips. For example: sharing the experience with other tourists, getting information from friends and relatives, making contact with other people interested in traveling (Cabiddu, De Carlo and Piccoli, 2014), talking about an event and trying to convince friends and relatives to attempt it (Kim, Lee and Bonn, 2016), as well as other personal benefits, as, for example, having fun using their social networks (Amaro, Duarte and Enriques, 2016).
Some authors have also examined the importance of self-presentation by tourists in social media (Luo and Zhong, 2015; Maldonado, 2012; Martín and Torres, 2013; Sun et al., 2014). Regarding this particular motivation, there seems to be a connection between perceived self-congruity and tourists' intensity of the use of social networks (Gonzales and Hancock, 2011; Hudson et al., 2015; Kim and Jang, 2014; Manago et al., 2009) as well as there seems to be a relationship between both constructs and the social value tourists' perceive from the experience (Bond and Falk, 2013; Chung and Koo, 2012; Kim, Lee and Bonn, 2015; Lyu, 2016; Molz, 2013; Munar and Jacobsen, 2014; Shanahan, 2009). Therefore, this research focuses on tourism self-congruity and its influence on the use of social networks. Furthermore, the research analyses the connection between those constructs with perceived social value and tourists' revisit intention.

\section{Literature review}

\section{Symbolic consumption}

First historical references of symbolic consumption appeared in the literature at the end of the nineteenth century and at the beginning of the twentieth century (Flügel, 1930; James, 1890; Simmel, 1903). These authors mentioned that customers reinforce their identities throughout the products they acquire. However, the analysis of this concept as a marketing variable didn't appear in the literature until the middle of the twentieth century, mainly influenced by Levy, who established that "managers must attend to more than the relatively superficial facts with which they usually concern themselves when they do not think of their goods as having symbolic significance" (Levy, 1959, p. 117).

Since then, many studies have focused on the analysis of the symbolic meanings of products and brands in the literature. In order to examine symbolic consumption as a concept, different definitions obtained from the literature are presented in Table 1.

As shown in Table 1, most of the authors focus on the relationship between products (or brands) and the consumer's identity when 
Table 1. Definitions of "symbolic consumption"

\begin{tabular}{|c|c|c|}
\hline Authors & Date & Definition of "symbolic consumption" \\
\hline Landon & 1974 & "Use of the symbolic content of brands in other to express one's identity" (p. 45). \\
\hline $\begin{array}{l}\text { Csikszentmihalyi } \\
\text { and Rochberg- } \\
\text { Halton }\end{array}$ & 1981 & $\begin{array}{l}\text { "Process of transaction between a consumer and an object, together with the } \\
\text { communicative signs of that process" (p. } 7) \text {. }\end{array}$ \\
\hline Belk & 1984 & $\begin{array}{l}\text { "Tendency of some buyers to add meaning to the products they acquire" ( } p \text {. } \\
\text { 266). }\end{array}$ \\
\hline McCracken & 1987 & $\begin{array}{l}\text { "Acquisition of products focused on qualities beyond functional attributes or } \\
\text { commercial values, and based meanly on the ability of those products to transfer } \\
\text { and communicate cultural meanings" ( }(\text {. 140). }\end{array}$ \\
\hline Lorenzi & 1991 & "Consumption action that takes part as a process of identity creation" (p. 405). \\
\hline Clammer & 1992 & $\begin{array}{l}\text { "Every act of consumption through which an individual pretends to project his or } \\
\text { her identity, interests and social position" (p. 196). }\end{array}$ \\
\hline Dittmar & 1992 & $\begin{array}{l}\text { "Acquisition and use of products based on the meaning they have, and derived } \\
\text { from what the possessor feels those products communicate to himself/herself } \\
\text { and also to other people" (p. 380). }\end{array}$ \\
\hline Ger and Belk & 1996 & $\begin{array}{l}\text { "Acquisition and possession of goods as a communicative act that is crucial to } \\
\text { an individual identity construction" (p. 57). }\end{array}$ \\
\hline $\begin{array}{l}\text { Edson and } \\
\text { Bettman }\end{array}$ & 2005 & $\begin{array}{l}\text { "Use of products as a mechanism of creation, development and preservation of } \\
\text { individuals' images" ( }(\text {. 382). }\end{array}$ \\
\hline Fenollar and Ruiz & 2006 & $\begin{array}{l}\text { "Importance given by a consumer to others opinion about symbolic evaluation of } \\
\text { products when those are conceived as social interaction tools" (p. 8). }\end{array}$ \\
\hline Park et al. & 2010 & $\begin{array}{l}\text { "Intention to project status, feeling of belonging or self-worth through the } \\
\text { consumption of goods and services that transmit symbolic values" (p. 3). }\end{array}$ \\
\hline Lee & 2013 & $\begin{array}{l}\text { "It appears when individuals use consumption and its meaning in order to } \\
\text { communicate something about themselves" (p. 175). }\end{array}$ \\
\hline Sun et al. & 2014 & $\begin{array}{l}\text { "Acquisition, creation, preservation and presentation of our existential identity } \\
\text { through consumption" (p. 55). }\end{array}$ \\
\hline
\end{tabular}

Source: own elaboration.

defining symbolic consumption. However, when it comes to its analysis as a marketing variable, researchers have examined symbolic consumption from different perspectives, for example:

- Analysis of the extrinsic meaning of possessions: Cueto (1981); Kastanakis and Balabanis (2012); Martín (1982); Naredo (1981).

- Conspicuous consumption: Amaldoss and Jain (2005); Bagwell and Bernheim (1996); Chaudhuri and Majumdar (2006); Corneo and Olivier (1997); Kim and Jang (2014).

- Materialism: Belk (1984); Dawson (1988); Dawson and Bamossy (1991); La Barbera and Gurhan (1997); Lipscomb (1988); Schroeder and Dugal (1995); Richins (1994a, 1994b); Richins and Dawson (1990, 1992); Richins, McKeage and Najjar (1992); Sangkhawasi and Johri (2007); Shrum, et al. (2013).

- Self-congruity: Edson and Bettman (2005); Fournier (1998); Giddens (1991); Grier and Deshpande (2001); Lee (2013); Park, et al. 156
(2010); Sirgy et al. (1995, 1998); Sun et al. (2014).

- Social influence in consumption: Edson and Bettman (2005); Fournier, (1998); Giddens (1991); Grier and Deshpande (2001); Lee (2013); Park, et al. (2010); Sirgy et al., (1995, 1998); Sun et al. (2014).

Most of these studies have traditionally focused on the symbolic consumption of tangible objects. However, some authors have recently analysed symbolic consumption of services and experiences (e. g. Arocena and Buffa, 2012; Chatzidakis and Lee, 2013; Ekinci, Sirakaya and Preciado, 2013; Rihova et al., 2015; Serra, 2013; Stokowski, 2011), including the examination of tourism symbolic consumption (Butler, Kevin and Prentice, 2012; Chen, Leask and Phou, 2016; Kim and Jang, 2014; Kim and Jun, 2016; Kumar and Nayak, 2014; Servidio, 2015; Sharma and Shruti, 2015; Uchiyama and Kohsaka, 2016). 
Thus, according to Servidio (2015) current tourists' motivations and needs become complex, and tourists demand symbolic meanings to be shared between their vacations and themselves. Also, tourists want to show others what they did during their trip, emphasizing the symbolic meanings of their tourism consumption (Chatzidakis and Lee, 2013; Serra, 2013). In this context, Kerr, Lewis and Burgess (2012) introduced the term "bragging rights" in a model intending to explain the benefits of managing the tourists' intention to communicate their experience to others.

When it comes to destination choice and symbolic consumption, the study by Chen, Leask and Phou (2016) shows that, currently in tourism "the effects of symbolic consumption are greater than that of functional consumption" (Chen, Leask and Phou, 2016, p. 1). Research on destination characteristics and symbolic consumption have been examined by various authors in the literature (see e. g. Ballesteros and Ramírez, 2007; Kim and Jun, 2016; Kumar and Nayak, 2014; Yuksel, Yuksel and Bilim, 2010). One of the main conclusions of these studies reveals that tourists may choose destinations that represent social status (Kumar and Nayak, 2014; Lin, Pearson and Cai, 2011; Phillip and Back, 2011).

In addition, researches by White and White (2009), Sidali, Kastenholz, and Bianchi (2013), Uchiyama and Kohsaka (2016) and Wang (2016) focus on the influence on satisfaction of the symbolic connection between local population at destination and the tourist's identity.

Other studies have examined tourism symbolic consumption in different areas, for example: mountain tourism (Silva, 2012); sport megaevents (Banyai and Potwarka, 2012); pilgrimage (Blom, Nilsson and Santos, 2016); and screen tourism (Kim, 2012). In all these contexts of analysis it is emphasized the importance of tourist companies giving their clients a service according to their identities (for example: ecological orientation) and reflecting the characteristics of such services in their communication channels. These affirmations are supported by Ekinci, Sirakaya and Preciado (2013), Gupta and Ahmad (2014) and Sharma and Shruti (2015).

As a construct, tourism symbolic consumption has been measure in the literature using different approaches, for example: materialistic tourism consumption (Kim and Jang, 2014); destination identification and lifestylecongruence (Nam, Ekinci and Whyatt, 2011; Chen, Leask and Phou, 2016); and tourism self-congruity (Ekinci, Sirakaya and Preciado, 2013).

Therefore, it is observed that self-congruity is one of the construct used in the literature in order to measure tourism symbolic consumption. Based on the objectives of this research, the next sub-section focuses on the examination of self-congruity in tourism.

\section{Self-congruity in tourism}

Self-congruity is a construct related to symbolic consumption in the literature (AguirreRodriguez, Bosnjak and Sirgy, 2012). Authors use different terms to refer to this construct; "self-image congruence", "self-congruence," "self-congruity", and "image congruence" are used interchangeably in the consumer behavior literature (Kressmann et al., 2006). Also, authors have provided different definitions in their researches. Some of the most important definitions are presented in Table 2.

As shown in Table 2, in order to conceptualize self-congruity, authors have typically focused in the relationship between products' image and consumers' self-concept.

Nonetheless, it is observed in the literature that self-congruity is considered a complex multidimensional construct. In 1982, Sirgy was first to consider four self-concept facets when analysing self-congruity: (1) actual self (how one actually perceives the self); (2) ideal self (the self one desires to become); (3) social self (the person one believes others perceive); and (3) ideal social self (the person one desires others to perceive). 
Table 2. Definitions of "self-congruity"

\begin{tabular}{|c|c|c|}
\hline Authors & Date & Definition of "self-congruity" \\
\hline $\begin{array}{l}\text { Grubb and } \\
\text { Grathwohl }\end{array}$ & 1962 & $\begin{array}{l}\text { "The link between psychological construct of and individual's self-concept and } \\
\text { the symbolic value of goods purchased in the marketplace" (p. 22). }\end{array}$ \\
\hline Ross & 1971 & $\begin{array}{l}\text { "Consumption of product or brands only when they are consistent, enhance, or in } \\
\text { some way, fit well with the conception consumers have of themselves" (p. 38). }\end{array}$ \\
\hline Sirgy & 1982 & $\begin{array}{l}\text { "The matching of the product user image with the consumer's self-concept" ( } p \text {. } \\
\text { 350). }\end{array}$ \\
\hline Graeff & 1996 & $\begin{array}{l}\text { "The process of buying products or brands that are perceived by consumers to } \\
\text { be similar to their own self-concept" }(p .5) \text {. }\end{array}$ \\
\hline Aaker & 1997 & $\begin{array}{l}\text { "Perceived consistency between brand personalities and targeted consumers' } \\
\text { self-concepts" ( } p .347) \text {. }\end{array}$ \\
\hline $\begin{array}{l}\text { Barone, Shimp } \\
\text { and Sprott }\end{array}$ & 1999 & $\begin{array}{l}\text { "Consumer's preference for the brand or product whose image most closely } \\
\text { corresponds to his/her own self-concept" }\end{array}$ \\
\hline $\begin{array}{l}\text { Sirgy, Grewal and } \\
\text { Mangleburg }\end{array}$ & 2000 & $\begin{array}{l}\text { "A process of matching a shopper's self-concept to an image during } \\
\text { consumption" (p. 127). }\end{array}$ \\
\hline $\begin{array}{l}\text { Quester, } \\
\text { Karunaratna and } \\
\text { Goh }\end{array}$ & 2000 & "Congruence between self-image and product-image" (p. 525). \\
\hline Jamal and Goode & 2001 & $\begin{array}{l}\text { "Individuals expressing themselves by choosing brands whose personalities are } \\
\text { perceived to be congruent with their own personalities" ( } p .483) \text {. }\end{array}$ \\
\hline Kressmann et al. & 2006 & $\begin{array}{l}\text { "The match between consumers' self-concept (actual self, ideal self, etc.) and } \\
\text { the user image (or "personality") of a given product, brand, store, etc." (p. 955). }\end{array}$ \\
\hline $\begin{array}{l}\text { Ibrahim and } \\
\text { Najjar }\end{array}$ & 2008 & "Consumers behaving consistently with their self perceptions" (p. 209). \\
\hline $\begin{array}{l}\text { Randle and } \\
\text { Dolnicar }\end{array}$ & 2011 & "Consumption of brands that reinforce individuals' self-concept" (p. 741). \\
\hline Cho and Kim & 2012 & “Consumers' behaviour in order to confirm their internal self-concepts” (p. 32). \\
\hline $\begin{array}{l}\text { Correia, Kozak } \\
\text { and Reis }\end{array}$ & 2014 & "Enhancement of self-conception through the consumption" (p. 3). \\
\hline Matzler et al. & 2016 & $\begin{array}{l}\text { "Consumers' preference of products/brands they consider as being similar to } \\
\text { themselves"(p. 507). }\end{array}$ \\
\hline
\end{tabular}

Source: own elaboration.

According to the dimensions of the construct, in the research by Sirgy, Grewal and Mangleburg (2000) the following relationships between selfcongruity and consumers' motives are established:

Actual self-congruity $\rightarrow$ Self-consistency motive Ideal self-congruity $\rightarrow$ Self-esteem motive Actual social self-congruity $\rightarrow$ Social consistency motive

Ideal social self-congruity $\rightarrow$ Social approval motive

These four dimensions of the construct are accepted by many authors in the literature, who analysed the relationship between selfcongruity and several variables in their studies, for example: consumers attitude (Johar and Sirgy, 1999); stores' image (Sirgy, Grewal and Mangleburg, 2000; Chebat, Sirgy and StJames, 2006); product choice (Quester, Karunaratna and Goh, 2000); satisfaction
(Ibrahim and Najjar, 2008; Jamal and Goode, 2001); adoption decisions (Kleijnen et al., 2005); brand loyalty (Kressmann et al., 2006; Randle and Dolnicar, 2011; Mazodier and Merunka, 2012); perceived quality (Chebat, Sirgy and St-James, 2006; Kwak and Kang, 2009); and purchase intentions (Ibrahim and Najjar, 2008).

In addition, according to the review by AguirreRodriguez, Bosnjak and Sirgy (2012) several variables have been analysed in the literature as moderators of perceived self-congruency and consumers' attitude/intention behaviour, for example: self-motive socialness, degree of selfenhancement sought, brand personality facet, product stimulus abstraction, impression formation process, and cognitive elaboration.

When it comes to its measurement, one of the most common ways of evaluating self-congruity 
is through the use of personality traits, which individuals use to describe their perceptions of self (Malhotra, 1988). Research showed that individuals are able to use personality traits not only to describe themselves, but also to differentiate between brands and to link those brands with themselves (Aaker, 1997). However, numerous researches used scales in order to measure self-congruence. A significant amount of these scales are based on the study by Sirgy et al. (1997), as shown in Table 3.

Furthermore, the studies showed in Table 3 focus on different areas of analysis, for example: retailing (Chebat, Sirgy and StJames, 2006; Ibrahim and Najjar, 2008; Sirgy et al., 2008); online retailing (Cho and Kim, 2012); volunteering organizations (Randle and Dolnicar, 2011); key chains (Barone, Shimp and Sprott, 1999); clothing (Ericksen and Sirgy, 1992); automobiles (Heath and Scott, 1998; Kressman et al., 2006) services (Yim, Chan and Hung, 2006); sport business (Kwak and Kang, 2009), and advertising (Azevedo and Farhangmehr, 2005).

Also, self-congruity has been used as one of the main constructs related to the analysis of symbolic consumption in the area of tourism (e. g. Ahn, Ekinci and Li, 2011; Chen, Leask and Phou, 2016; Hung and Petrick, 2012; Kim and Jun, 2016; Matzler et al., 2016; Qu and $Q u$, 2015). These researches suggest that selfcongruity has a positive influence on pre-trip visitation interest and purchase proclivity (Ahn, Ekinci and Li, 2011; Beerli, Díaz and Moreno, 2007; Litvin and Goh, 2002; Souza, 2015) as well as on post-trip travel consequences and intentions (Bosnjak et al., 2011; Kastenholz, 2004; Matzler et al., 2016).

One of the most repeated pre-trip visitation constructs in the literature is destination choice (Ahn, Ekinci and Li, 2011; Beerli, Díaz and Moreno, 2007). For instance, Kastenholz (2004), and later Hung and Petrick (2012), analysed the effects of self-congruity in this context of research. As a result, they suggested that "the more congruent images are, the more likely people would intend to travel" (Hung and Petrick, 2012, p. 857). This affirmation was latter supported by Doran,
Larsen and Wolff (2015) and $\mathrm{Qu}$ and $\mathrm{Qu}$, (2015).

More recently, Matzler et al. (2016) indicated that self-congruity can be a mediator of the relationship between tourism brand personality perception and visit intention. Kim and Jun (2016) also considered that self-congruity affects tourists' destination choices indirectly, through tourists' attitude towards a destination. And Gazley and Watling (2015) confirmed that "when making consumption decisions, a tourist forms perceptions based on the likelihood that the product or experience will be congruent with their self' (p. 639).

When it comes to post-trip consequences, authors have analysed the relationship between self-congruency and constructs as satisfaction (Chon, 1992; Liu, Lin and Wang, 2012), loyalty (Yuksel, Yuksel and Bilim, 2010), intention to recommend (Ekinci, Sirakaya and Baloglu, 2007; Han and Back, 2008; Usakli and Baloglu, 2011) and revisit intention (Beerli, Meneses, and Gil 2007; Bosnjak et al., 2011; Kastenholz 2004).

According to the research goals of the present study, and in order to establish the first hypotheses of this investigation, the next subsection focuses on experience self-congruity and posttrip consequences, especially centered on tourists' perceived social value and revisit intention.

Experience self-congruity, perceived social value and revisit intention

In 2007, Ballesteros and Ramírez pointed out that a community is formed by members who shared common identities. When it comes to tourism, a community can emerge through common experiences and the shared use of contexts of meaning; these contexts of meaning shape situations in which the participants create social value. In connection with that, Kim and Jun (2016) explained that tourists associate symbolic meanings with a destination, and this has an effect on perceived value.

For Gazley and Watling (2015), when consuming an experience abroad, tourists look beyond functional utility to social meaning. And 
The influence of tourism experience self-congruity on the use of virtual social networks.

Table 3. Scales used in the literature in order to measure Self-congruency

\begin{tabular}{|c|c|c|}
\hline $\begin{array}{l}\text { Authors and } \\
\text { date }\end{array}$ & Scale & Characteristics of the scale \\
\hline $\begin{array}{l}\text { Barone, Shimp } \\
\text { and Sprott } \\
(1999)\end{array}$ & Rosenberg's (1965) & $\begin{array}{l}\text { Ten items that measure the perceived level of congruence between an } \\
\text { object and their self-image. The items focus on social self-congruence (e. g. } \\
\text { For me to own this item would be looked o favorably by my friends; My } \\
\text { friends would evaluate my owning this item in positive terms). }\end{array}$ \\
\hline $\begin{array}{l}\text { Johar and Sirgy } \\
\text { (1999) }\end{array}$ & $\begin{array}{l}\text { Self-made based on } \\
\text { Sirgy et al. (1997). }\end{array}$ & $\begin{array}{l}\text { Measured by the summation of scores from four self-congruity constructs: } \\
\text { actual self-congruity ( } 10 \text { items), ideal self-congruity (10 items), social self- } \\
\text { congruity ( } 10 \text { items), and ideal social self-congruity ( } 10 \text { items). }\end{array}$ \\
\hline $\begin{array}{l}\text { Quester, } \\
\text { Karunaratna } \\
\text { and Goh (2000) }\end{array}$ & $\begin{array}{l}\text { Self-made scale } \\
\text { based on Sirgy et al. } \\
(1985)\end{array}$ & $\begin{array}{l}\text { A series of items were separated in two sections, in order to measure actua } \\
\text { and ideal self-image. }\end{array}$ \\
\hline $\begin{array}{l}\text { Jamal and } \\
\text { Goode (2001) }\end{array}$ & $\begin{array}{l}\text { Adapted from Sirgy et } \\
\text { al. (1997). }\end{array}$ & Two items that measures actual self-congruence. \\
\hline Kang (2002) & $\begin{array}{l}\text { Self-made based on } \\
\text { Sirgy et al. (1997) }\end{array}$ & $\begin{array}{l}\text { Adopted from Sirgy et al. (1997) in order to measure the degree of image } \\
\text { congruence between self and stereotypic image of sport participants. }\end{array}$ \\
\hline $\begin{array}{l}\text { Litvin and Goh } \\
(2002)\end{array}$ & $\begin{array}{l}\text { Adapted from the } \\
\text { scale by Malhotra } \\
(1988)\end{array}$ & $\begin{array}{l}\text { For each item, the respondents evaluated their actual self-concept by } \\
\text { answering the question: "Using the following list of adjectives, how do you } \\
\text { see yourself?", and their ideal self-concept by answering: "How would you } \\
\text { like to see yourself?" }\end{array}$ \\
\hline $\begin{array}{l}\text { Kastenholz } \\
(2004)\end{array}$ & $\begin{array}{l}\text { Adapted from Sirgy et } \\
\text { al. (1997) }\end{array}$ & $\begin{array}{l}\text { The scale adds a series of questions related to attributes of the product } \\
\text { where respondents answered in a scale if those attributes matched their } \\
\text { self-image (from very similar to very different). }\end{array}$ \\
\hline $\begin{array}{l}\text { Chebat, Sirgy } \\
\text { and St-James } \\
(2006)\end{array}$ & Sirgy et al. (1997). & $\begin{array}{l}\text { Three items (e.g. "I can identify with the typical customer who shops at this } \\
\text { shopping center") that measure actual self-congruence. }\end{array}$ \\
\hline $\begin{array}{l}\text { Kressmann et } \\
\text { al. (2006) }\end{array}$ & Aaker's (1997) & $\begin{array}{l}\text { The self-congruity scores were computed using absolute difference scores } \\
\text { between each brand personality ratings and its corresponding self-image } \\
\text { ratings (actual and ideal self-image), and then averaged across all } \\
\text { personality attributes for each respondent. }\end{array}$ \\
\hline $\begin{array}{l}\text { Yim, Chan and } \\
\text { Hung (2006) }\end{array}$ & $\begin{array}{l}\text { Scale adapted from } \\
\text { Chon (1992). }\end{array}$ & $\begin{array}{l}\text { Four items that measure the congruence between the service and } \\
\text { consumer's self-image. }\end{array}$ \\
\hline $\begin{array}{l}\text { Beerli, Díaz and } \\
\text { Moreno (2007) }\end{array}$ & $\begin{array}{l}\text { Adapted from the } \\
\text { scale by Malhotra } \\
(1981)\end{array}$ & $\begin{array}{l}\text { For each item, the respondents evaluated their real self-concept by } \\
\text { answering the question: "Using the following list of adjectives, how do you } \\
\text { see yourself?", and their ideal self-identity by answering: "How would you } \\
\text { like to see yourself?" }\end{array}$ \\
\hline $\begin{array}{l}\text { Ibrahim and } \\
\text { Najjar, (2008) }\end{array}$ & Self-made scale & $\begin{array}{l}\text { The scale was made through a study involving item development and } \\
\text { reliability assessment, resulting in } 21 \text { items that measures actual and ideal } \\
\text { self-congruity. }\end{array}$ \\
\hline $\begin{array}{l}\text { Kwak and Kang } \\
\text { (2009) }\end{array}$ & Kang (2002) & $\begin{array}{l}\text { A four-item scale was adopted from Kang's (2002) self-participant image } \\
\text { congruence scale. }\end{array}$ \\
\hline $\begin{array}{l}\text { Boo, Busser } \\
\text { and Baloglu }\end{array}$ & $\begin{array}{l}\text { Adapted from Sirgy et } \\
\text { al. (1997) }\end{array}$ & $\begin{array}{l}\text { Four items that measure the degree of customer self-image and social } \\
\text { image. }\end{array}$ \\
\hline
\end{tabular}

(2009)

Randle and

Dolnicar (2011) based on Kressmann

Cho and Kim Poddar, Donthu and

(2012) Wei's (2009)

Mazodier and Sirgy et al. (1997)

Merunka (2012)

Hung and

Petrick (2012)

Adapted from Baloglu and Love (2005)

\section{Self-made}

Correia, Kozak

Kirillova, Xinran

and Cai (2016)

Lenton et al. (2013)
Self-made scale et al. (2006)

The scale measures the congruence between a series of attributes of an organization and the individuals' self-image.

Congruity scores were calculated by the gap score formula as following: Self-congruity $=\Sigma$ Online store personality - Self personality|.

Three items scale adapted from Sirgy et al. (1997).

The scale doesn't focus on the congruency between the object and the consumer's self-concept, but on a series of parameters based on the study by Baloglu and Love (2005): Exciting-gloomy / Pleasant-unpleasant (ISC3) / Relaxing-distressing / Enjoyable - not enjoyable / Comforting uncomforting / Calming - annoying / Fun-boring.

A series of items measuring self-fulfillment and social identity.
A measurement instrument consisting of six pairs of circles with varying degrees of overlap between them. The left circle symbolized 'tourism experience', while the right circle of each pair represented 'who you truly are'. The participants marked a pair of circles that 'best represents how close you feel that the tourism experience represents your real self.' 
Kim and Jang (2014) indicated that consumers choose experiences following materialistic tendencies, related to the perceived social value of the experience.

Furthermore, in the study by Correia, Kozak and Reis (2014) there is a relationship between conspicuous consumption, self-congruity and perceived social value. Respondents in this qualitative study associate conspicuous tourism experiences with being recognized and with gaining popularity. Social value is examined in this research based on the fact that respondents affirmed they photographed everything, to show others they lived experiences congruent with their lifestyles, and they expected it would confer social recognition upon them.

Murphy, Benckendorff and Mascardo (2007), Kwak and King (2009), Sparks, Bradley and Jennings (2011) and Hosany and Martin (2012) supported in their researches the affirmation that perceived value of a brand can be affected by self-congruity. Based on these studies, the following hypothesis is established:

H1:Experience self-congruity directly and positively influences the perceived social value of the experience.

When it comes to revisit intention, on the one hand Beerli, Díaz and Moreno (2007) suggested that "self-congruity loses its determining power when one has already visited a place" (p. 571). On the other hand, Ekinci, Sirakaya and Baloglu (2007) mentioned that destination self-congruity has a positive influence on both intention to return and word of mouth. Also, Usakli and Baloglu (2011) suggested that "the congruency between a tourists and the experience has a positive influence on tourists' intention to return" ( $p$. 114). And for Aaker (1997), the greater the match between the destination personality and the tourist's self-concept, the more likely it is that the tourist will have a favorable attitude toward that destination. This attitude can be based on others' responses, and may result in an intention to return (Aaker, 1997).

Furthermore, in the study by Chew and Jahari (2014) is indicated that the congruity between the consumer's image and the destination's image has an effect on perceived social value, since "it might affect others' opinion of the consumer" (p. 386), and these opinions influence tourists' revisit intention.

In addition, social value could arise from "the approval of reference groups toward the choice of destination" and "consequently, a positive destination image would exude positive future behavioral intentions" (Kim and Jang, 2014, p. 387). Also "individuals compare themselves with other people to show they are trendy or keeping up with peers" (Kim and Jang, 2014, p. 5). Therefore, Kim and Jang (2014) proposed that perceived social value can trigger consumers' intention to revisit a place. Based on these affirmations, the following hypothesis is established:

H2:Perceived social value of the experience directly and positively influences revisit intention.

Subsequently, and according to the main purpose of the present study, the next subsection focuses on the relationship between tourists' use of social media, self-congruity and social value.

Tourists' use of social media, self-congruity and perceived social value

Social media is a "group of Internet-based applications which build on the ideological and technological foundations of Web 2.0 and which allow the creation and exchange of user generated content' (Cabiddu, De Carlo and Piccoli, 2014, p. 175). There are different reasons that explain user generated content in social media. One of the most important reasons is the motivation of sharing opinions and interests, a phenomenon also known as eWOM (Cantallops and Salvi, 2014; Cheung and Thadani, 2012; Ladhari and Michaud, 2015). Although the relationship between psychologically driven motivations and eWOM is still an open question (Cobasky, 2016), one of the main conclusions of the studies of eWOM is that positive sentiments about products and services are more likely to be shared on the internet (Kim and Jang, 2014; Cobasky, 2016). Due to eWOM, social networks have become important information 
sources for current travelers (Amaro, Duarte and Enriques, 2016; Okazaki and Hirose, 2009; Xiang and Gretzel, 2010).

Other reasons of the use of social media by tourists are: making contact with other people interested in traveling (Colás, González and De Pablos (2011); publishing personal experiences (journalism) (Cabiddu, De Carlo and Piccoli, 2014); talking about an event and trying to convince friend and relative to attempt it (Kim, Lee and Bonn, 2016); as well as other benefits, as, for example, having fun using a social network (Amaro, Duarte and Enriques, 2016).

In this context of research, it has been established that some tourists use their virtual social networks for self-presentation, in order to express personal aspects of their identities that are in other ways difficult to express (Luo and Zhong, 2015; Maldonado, 2012; Martín and Torres, 2013; Sun et al., 2014). The act of selfpresentation through virtual social networks is sometimes motivated by the tourists' need for belonging and their need for sharing their status (Lenhart and Fox, 2006).

According to Bond and Falk (2013), the more important a role is to an individual the more that individual will commit to it; the stronger this commitment is the more salient the role is to a person's identity; lastly, the more salient the role is to that identity, the more a person will engage in behaviors to express the role. Thus, individuals want to show others the experiences they lived and they look for ways to be able to do it. Some authors have recently highlighted souvenirs buying and social media posting as some of the most important tourists' actions in order to reinforce their identities after a tourism experience (Boley, Magnini and Tuten, 2013).

Other authors have mentioned that, when there is an attachment with a tourism experience, tourists tend to use more their social networks (Gonzales and Hancock, 2011; Hudson et al., 2015; Kim and Jang, 2014; Manago et al., 2009). This attachment can be influenced by the perceived congruity between the experience and the tourist's self-concept (Kim and Jang, 2014).
In connection with that, Gonzales and Hancock (2011) affirmed that in social media "consumers present more positive information about the self while filtering negative information" (Gonzales and Hancock, 2011, p. 79). Furthermore, individuals tend to engage in a social networks with other individuals with common identities (Ren et al., 2012; Ren, Kraut and Kiesler, 2007), as well as they create more content about subjects related to these identities (Kim, Lee and Bonn, 2015). Based on these affirmations, the following hypothesis is established:

H3:Experience self-congruity directly and positively influences the use of virtual social networks.

When it comes to the relationship between social media and perceived social value, according to Hwang and Kim (2015), "internetbased communication can be regarded as a means of reinforcing existing relationships and even increasing social capital by extending the spheres of social contact and fostering the globalization of many ties" (p. 481). Therefore, "social media can be an effective method for coping with social disconnection, as it enables peer acceptance and relationship development and boots self-esteem" (Seidman, 2013, p. 402).

Kim, Lee and Bonn (2015) explained that social media usage is found to interact with measures of psychological well-being, suggesting that it provides greater benefits for users experiencing low life satisfaction by assessing bonding and bridging related to social capital. Some researches in the literature have considered that identity attachment can be formed by online knowledge sharing, and the used of social sites can lead to perceived social value (see e. g. Bond and Falk, 2013; Chung and Koo, 2012; Hudson et al., 2015; Kim, Lee and Bonn, 2015; Lyu, 2016; Molz, 2013; Munar and Jacobsen, 2014; Shanahan, 2009). For example, the study by Molz (2013), based on the social network "Coachsurfing", explains how social media helps tourists bonding before, during and after their holidays. One of the main uses of social media by tourists after their trips is sharing content with other tourists, what adds social value to the experience. 
For Munar and Jacobsen (2014) "sharing practices through social media appear as valuable articulations of sociability and emotional support" (p. 46). For these authors, identifying as a part of a community is an important factor of tourists' generated content. In addition, tourists select and post information they consider congruent with the image they want to show to others.

Also, tourists believe that talking about their experience helps others in some way (informational or recreational), indicating values of virtual community cultures, and the recognition as a good provider of resources may raise a person's status within the group (Ooi and Ek, 2010). Moreover, "although tourists may have a tendency to employ altruistic and community-related terms when explaining reasons for their sharing behaviour, they may also be aiming at individual benefits such as strengthened reputation or increased feelings of self-efficacy" (Munar and Jacobsen, 2014, p. 48).

Lyu (2016), in a study center on travel selfies posted on social media as objectified selfpresentation, explained that, when tourists use social networks in order to talk about the experience, they perceived more value of the experience they lived, because, normally, they receive positive responses and compliments. In fact, "anticipated beneficial consequences encourage social media users to purposefully fabricate their images. Specifically, many people have a belief that probability of acquiring preferred outcomes, including others' approval and support, increases when desirable impressions are circulated through online channels" (Lyu, 2016, p. 186).

Based on these affirmations, the following hypothesis is proposed:

H4:The use of digital social networks directly and positively influences the perceived social value of the experience.

Furthermore, based on previous studies, there might be an added relationship between these two constructs, since perceived social value might at the same time increase the use of social media. For example, Okazaki and Hiroze (2009) and Luo and Zhong (2015) pointed out that some factors as social class and selfcongruity influence information processing and consumers' generation content in social media. And, Kim and Tussyadiah (2013) stated that the high level of social presence and selfdisclosure on the intern et allows tourists to refer to their social networks for acceptable behavior and good judgment.

These affirmations are connected with the fact that people are concerned about reactions of others as reference groups. The theory of selfconcept indicates that consumers value consumption that results in recognition and reinforces reactions from the social network, so as to strengthen the conception about themselves (Tussyadiah, Kausar and Soesilo, 2015).

Rihova et al. (2015) stated that value is socially constructed and embedded in tourists' social practices, since: "in the course of their social experiences, tourists bond, cement social relationships and enhance their social skills thus co-creating value" (p. 356). In this context of analysis, tourists may want to keep in touch with other people with whom they shared a bond during their vacations, and in order to do that they may use their social networks (Nusair, Bilgihan and Okumus, 2013). Therefore, perceived social value due to the interaction during vacations with other tourists may influence the use of social media (Rihova et al. (2015). Also, when tourists perceived that a trip provided them social value they use social media to talk about a topic of interest with other geographically dispersed friends (Nusair, Bilgihan and Okumus, 2013).

For Ayeh, Au and Law (2013) tourists generate more content when they are creating information about a topic of interests of friends. Thus, "in studies on social groups, shared interests, values and passion symbolize the basis for consumers' interaction. This tendency might have led to the rapid increase in numerous online communities based on shared interest. The resultant websites have yielded enormous amounts of generated-content" (Ayeh, Au and Law, 2013, p. 135).

Finally, Gyimothy (2013) explained that, as in other social networks, on the internet users establish hierarchies and share information 


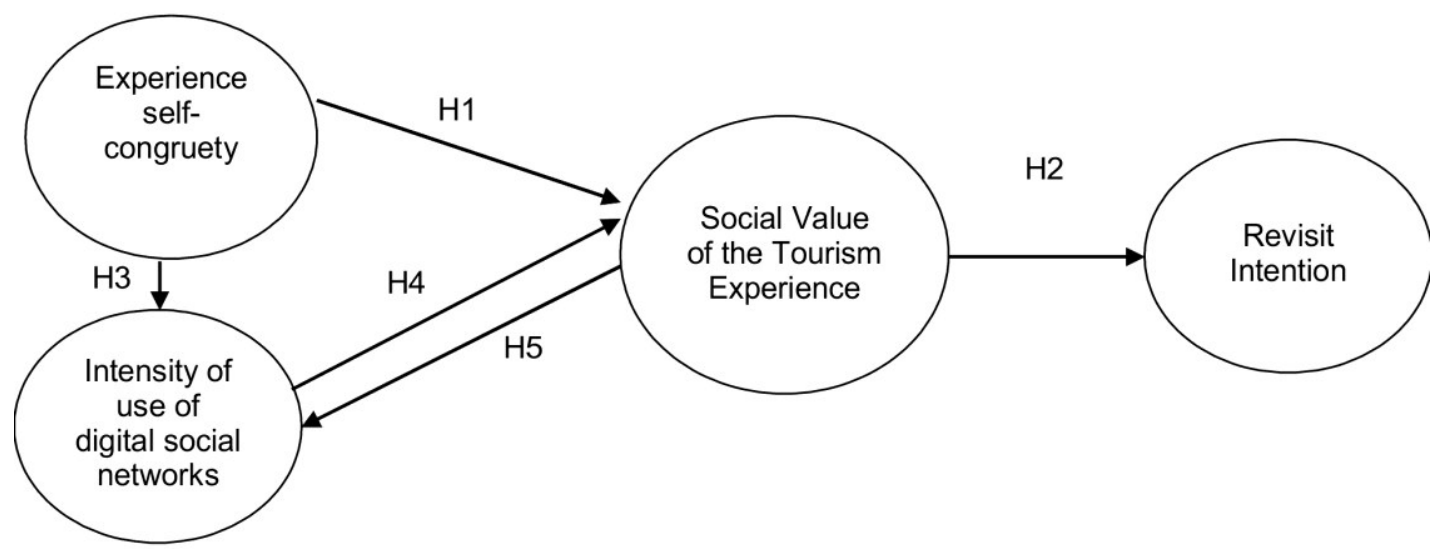

Fiqure 1. Empirical model

about their experiences in order to achieve higher ranks. Thus, consumers tend to talk about personal experiences when they think it conferred social value (Gyimothy, 2013; Olufwote, 2006; Weick, 1995). Based on these previous studies, the following hypothesis is proposed:

H5: The perceived social value of the experience directly and positively influences the use of digital social networks.

Figure 1 shows the empirical model built by the hypotheses of his research.

\section{Methodology}

\section{Data Collection}

An exploratory research was performed in order to achieve the proposed goals and to contrast the hypotheses. More precisely, a quantitative research was carried out by using a structured survey and personal interviews. The universe of the study was based on students of the University of Valencia (Spain) who came back recently from their vacations. The selection of the sample was performed by non-probability sampling trials.

The students were interviewed in different places around the university (the cafeteria of the campus, places where they relax near the library and other resting spots in the campus of the university). The interviewer explained them that the survey was a part of a project conducted by the University of Seville, and were invited to participate in the study. As a result, 380 valid surveys were collected during October of 2013, near the longest vacation time in Spain for students: summer vacation (months of July, August and September).

\section{Questionnaire design}

In order to introduce the respondents, the questionnaire explained them that the survey was a part of a project conducted by the University of Seville, and invited them to participate in the study. Subsequently, two filter questions were asked in order to know: (1) if they traveled for holidays at least one time in the last two months (in case the answer was "no" respondents were asked to stop completing the survey); and (2) if during or after their vacations they posted pictures, videos or comments about the trip on their social network sites $(100 \%$ of the respondents used some digital social network in order to show their experience during and after their vacations).

After that, respondents were asked to remember their trip and to answer the questions of the questionnaire, formed by scales related to the constructs of this study. These scales were selected from the literature review. Thus, the scale by Sirgy et al. (1997) was adapted to this study in order to measure experience self-congruity and ideal selfcongruity (questions 1-3: actual self; questions 4-5: ideal self). This scale has been used by several authors in the literature (Chon, 1992; Sirgy et al. 1995; Litvin and Goh, 2002; 
Table 4. Items of the scales

\begin{tabular}{|c|c|}
\hline $\begin{array}{l}\text { Self- } \\
\text { Congruence }\end{array}$ & $\begin{array}{l}\text { - I completely identify myself with the tourism experience I lived during my last trip } \\
\text { - This tourism experience is a lot like me } \\
\text { - This tourism experience reflects what I am } \\
\text { - Living this kind of tourism experience is consistent with how I like to see myself } \\
\text { - The experience I lived corresponds to how I like to see myself }\end{array}$ \\
\hline $\begin{array}{l}\text { Perceived } \\
\text { Social Value }\end{array}$ & $\begin{array}{l}\text { - This tourism experience helps me to feel acceptable } \\
\text { - This tourism experience improves the way I am perceived } \\
\text { - This tourism experience makes a good impression on other people } \\
\text { - This tourism experience gives me social approval }\end{array}$ \\
\hline $\begin{array}{l}\text { Intensity of } \\
\text { used of social } \\
\text { networks }\end{array}$ & $\begin{array}{l}\text { - Uploading information about the tourism experience I lived in my social network was an } \\
\text { important part of my daily routine during and after my trip } \\
\text { - I was proud of people reading and watching the information I uploaded in my social network } \\
\text { about the tourism experience I lived } \\
\text { - During my trip and after it, using my social network to talk about my trip was an important } \\
\text { activity for me, every day } \\
\text { - I felt out of touch when I couldn't log onto my social network during and after my trip in order } \\
\text { to give information about it } \\
\text { - During and after my trip I felt I was giving information to a social community that we have } \\
\text { created in our social network } \\
\text { - I would be sorry if my social network shut down and I couldn't give information about my } \\
\text { trips }\end{array}$ \\
\hline $\begin{array}{l}\text { Intention to } \\
\text { revisit }\end{array}$ & - I intent to revisit the destination of my last trip in order to live this tourism experience again \\
\hline
\end{tabular}

Mazodier and Merunka, 2012). Although most of the authors mentioned the four dimensions of self-congruity in their studies, the majority of them focus on the two first dimensions (actualself and ideal-self) when measuring the construct (see Beerli, Díaz and Moreno, 2007; Ibrahim and Najjar, 2008; Kang, 2002; Karunaratna and Goh, 2000; Kressmann et al., 2006; Litvin and Goh, 2002; Mazodier and Merunka, 2012; Quester, Karunaratna and Goh, 2000). The social dimension of the scale by Sweeny and Soutar (2001) was adapted to measure perceived social value; the scale by Jones et al. (2000) was used in order to measure revisit intention; and the scale by Ellison et al. (2007) was used to measure intensity of the use of digital social networks. Table 4 shows the items of the scales.

Respondent answered to each item in a Likert scale of seven points (from 1-totally disagree to 7-totally agree).

Finally, the questionnaire asked the respondents to answer the questions related to the socio-demographic characteristics of the sample. The respondents gave information about their gender, age, educational level and job situation. According to this information, 57\% of the respondents were women and $43 \%$ were men. The age of the respondents vary considerably, but more than $90 \%$ of the sample was between 20 and 35 years old. More than $75 \%$ of the respondents were study at under degree level and less than $30 \%$ had a job.

\section{Methodology used for data analysis}

Before testing the hypotheses, the reliability and the validity of the scales were verified by confirmatory factor analysis (CFA), using EQS 6.1. The methodology of the structural equation models (SEM) was used with EQS 6.1, in order to evaluate the structural model and to estimate the set of coefficients for the causal relations between variables.

\section{Results}

\section{Measurement instrument validation}

Convergent validity is demonstrated since all the items were found to have significant factor loads over 0.60 (Bagozzi and Yi, 1988) and the Lagrange multipliers test did not suggest significant relations for a factor other than those for which they were indicators (Hatcher, 1994). The model showed a significant good fit, presenting a Chi-square of 2956,707 on 153 
Table 5. Reliability and convergent validity

\begin{tabular}{lllrrrc}
\hline \multicolumn{1}{c}{ Factor } & Indicator & Load & Robust t & Cronbach's $\alpha$ & CR & AVE \\
\hline Self-congruity & CON1 & $0.762^{\star *}$ & 8.885 & 0.707 & 0.706 & 0.662 \\
& CON2 & $0.779^{\star *}$ & 17.101 & & & \\
& CON4 & $0.913^{\star *}$ & 10.146 & & & \\
& CON5 & $0.792^{\star *}$ & 13.554 & & & \\
Intensity of use of social networks & RED1 & $0.796^{\star *}$ & 5.659 & 0.715 & 0.759 & 0.731 \\
& RED2 & $0.717^{\star *}$ & 7.790 & & & \\
& RED3 & $0.985^{\star *}$ & 9.408 & & & \\
& RED4 & $0.853^{\star *}$ & 6.457 & & & \\
Revisit intention & RED5 & $0.765^{\star *}$ & 9.356 & & & \\
Social Experience Value & RED6 & $0.979^{\star *}$ & 10.275 & & & \\
& INREC & $0.907^{\star *}$ & 9.208 & - & 0.836 & 0.822 \\
& VALS1 & $0.768^{\star *}$ & 9.017 & 0.920 & 0.722 & 0.682 \\
& VALS2 & $0.779^{\star *}$ & 12.609 & & & \\
& VALS3 & $0.905^{\star *}$ & 10.380 & & & \\
\hline
\end{tabular}

$\mathrm{N}=380 ;{ }^{* *} \mathrm{p}<0.01 ;{ }^{*} \mathrm{p}<0.05 ; \mathrm{N} / \mathrm{A}=$ not computed; $\mathrm{x} 2=2956.707$ on $\mathrm{df}=153 ; \mathrm{NNFI}=0.957 ; \mathrm{CFI}=0.968 ; \mathrm{IFI}=0.969 ;$ RMSEA $=0.073$.

Table 6. Discriminant validity

\begin{tabular}{lrrrr} 
& Congruency & Intensity & Revisit & Exp. Value \\
\hline Congruency & $\mathbf{0 . 6 6 2}$ & $(0.192-0.301)$ & $(0.085-0.161)$ & $(0.091-0.387)$ \\
Itensity & 0.060 & $\mathbf{0 . 7 3 1}$ & $(0.061-0.277)$ & $(0.139-0.219)$ \\
Revisit & 0.015 & 0.028 & $\mathbf{0 . 8 2 2}$ & $(0.352-0.788)$ \\
Exp. Value & 0.571 & 0.032 & 0.324 & $\mathbf{0 . 6 8 2}$ \\
\hline
\end{tabular}

Note: The diagonal represents the average variance extracted AVE. Above the diagonal is the $95 \%$ confidence interval for the inter-factor correlations. Below the diagonal is the variance shared by each pair of factors (squared correlation).

degrees of freedom. And several indicators also showed the measurement model presents good fit (see it at the bottom of Table 5).

Reliability was measured with Cronbach's alpha. The threshold value for this coefficient is 0.70 , what guarantees internal consistency of the scales (Nunnally and Bernstein, 1994). As Table 5 shows, all Cronbach's a (Cronbach, 1951) were above the recommended value of 0.70 (Nunnally and Bernstein, 1994). The composed reliability index was also calculated and for all values it was over the recommended value of 0.70 (Fornell and Larcker, 1981). Average variance extracted (AVE) values were over 0.50 (Fornell and Larcker, 1981) (see Table 5).

Discriminant validity was evaluated following two criteria (see Table 6). Firstly, it was found that none of the $95 \%$ confidence intervals for correlation estimations between the pairs of factors contained the value 1 (Anderson and Gerbing, 1988). Secondly, the variance shared between each pair of constructs (squared correlation), was below the corresponding variance extracted indexes (Fornell and Larcker, 1981).

\section{Estimation of the conceptual model}

Table 7 shows verification of the hypotheses for the whole sample. It can be seen that the five hypotheses are supported. Thus, higher congruency between experience and identity leads to higher social value ( $\mathrm{H} 1$ supported); higher social value leads to higher revisit intention ( $\mathrm{H} 2$ supported); higher congruency between experience and identity leads to a higher intensity of the use of digital social networks ( $\mathrm{H} 3$ supported); a higher intensity of the use of digital social networks leads to higher social value (H4 supported); and a higher social value leads to an increase in the intensity of the use of social networks (H5).

\section{Discussion}

Based on the results, the first hypothesis of the proposed model was supported. Thus, it can be stated that there is a relationship between tourists' self-congruity and perceived social 
Table 7. Hypotheses testing

\begin{tabular}{lrrr}
\hline \multicolumn{1}{c}{ Relation } & \multicolumn{1}{c}{$\boldsymbol{\beta}$} & $(\mathbf{t})$ & Hypothesis \\
\hline H1: Self-congruency $\rightarrow$ Exp. Value & $0.330^{* *}$ & 5.728 & Accepted \\
H2: Exp. Value $\rightarrow$ Revisit Intention & $0.876^{* *}$ & 7.583 & Accepted \\
H3: Self-congruency $\rightarrow$ Social Net. Use & $0.422^{* *}$ & 4.196 & Accepted \\
H4: Social Net. Use $\rightarrow$ Exp. Value & $0.335^{* *}$ & 4.530 & Accepted \\
H5: Exp. Value $\rightarrow$ Social Net. Use & $0.262^{* *}$ & 2.665 & Accepted
\end{tabular}

$\mathrm{N}=380 ;{ }^{* *} \mathrm{p}<0.01 ;{ }^{*} \mathrm{p}<0.05 ; \mathrm{N} / \mathrm{A}=$ not computed; $\mathrm{X} 2=2956.707$ on df $=153 ; \mathrm{NNFI}=0.957 ; \mathrm{CFI}=0.968 ; \mathrm{IFI}=$ $0.969 ;$ RMSEA $=0.073$

value. This hypothesis was based on previous research (e. g. Ballesteros and Ramírez, 2007; Gazley and Watling, 2015; Hosany and Martin, 2012; Correia, Kozak and Reis, 2014). However, some of these studies did not measure the relationship through a quantitative research. For example, the study by Ballesteros and Ramírez (2007) highlighted the effects of social identities and the role of the symbolic community in the development of heritage tourism, but only theoretically, since no statistical data was presented in order to establish the relationship of the constructs. And Correia, Kozak and Reis (2014) also pointed out that self-congruency can influence perceived social value, but they conducted a qualitative research, and the results are based on the commentaries of thirty six Portuguese citizens who were interviewed after an event.

In the quantitative research by Kim and Jun (2016), in order to measure self-congruity, the authors used a similar scale as the one of the present research, but their study focuses on self-congruity and pre-trip decision making. Furthermore, Hosany and Martin (2012) focused on self-congruity and post-trip consequences and, although they did not measure the relationship between this construct and perceived social value, they confirmed that self-congruity influences satisfaction. In addition, the authors highlighted that, in this context of research, satisfaction can be based on the perception of social distinction. These findings are similar to the conclusions of the research by Kim and Jang (2014), who indicated that consumers choose experiences related to the perceived social value of the experience, and social value influences postexperience behavioural intentions. Therefore, the first hypothesis of this research supports these affirmations.
The second hypothesis was also supported, which indicates that perceived social value influences tourists' revisit intention. There are different opinions regarding this relationship in the literature. For example, Beerli, Díaz and Moreno (2007) affirmed that constructs related to symbolic consumption, as self-congruity and social value, might not be main predictors of revisit intention, because after visiting a destination the influence of these constructs are weaker. However, the theoretical foundation of the relationship in this study is based on a single research focused on advertising efficiency (Johar and Sirgy, 1999), which concludes that "the difference in selection mechanisms occurs between those who are familiar with the product or brand being advertised and those who are not" ( $p$. 575). Beerli, Díaz and Moreno (2007) also states that "no work has been found that measures the moderating function of experience related to the mechanism of selfcongruity as a decisive factor in destination choice" (p. 575). However, some authors in the literature have demonstrated that both selfcongruity and social value do influence revisit intention (e. g. Aaker, 1997; Chew and Jahari, 2014; Ekinci, Sirakaya and Baloglu, 2007; Usakli and Baloglu, 2011). This is based on the fact that other people's reactions (Chew and Jahari, 2014) perception of social approval (Kim and Jang, 2014) and social congruity (Ekinci, Sirakaya and Baloglu, 2007) are variables related to perceived social value that affect tourists' intention to return to destination (Usakli and Baloglu, 2011). Therefore, the second hypothesis of the present study supports the affirmations by these last authors, and strengthens the fact that perceived social value, as a consequence of self-congruity, influences tourists' revisit intention.

Furthermore, one of the main objectives of this research was to find a connection between 
experience self-congruity and tourists' use of social networks. It is established in the literature that there is a relationship between experience self-congruity and intention to recommend (Ekinci, Sirakaya and Baloglu, 2007), both offline and online (Cantallops and Salvi, 2014; Cheung and Thadani, 2012; Ladhari and Michaud, 2015). More precisely, Boley, Magnini and Tuten (2013) indicated that posting pictures on social networks after the experience is one of the main tourists' actions for self-presentation. And Kim, Lee and Bonn (2015) stated that tourists create more content in social networks about subjects related with their identities and lifestyles. Thus, the findings of the present research support previous connections between constructs related to symbolic consumption and tourists' selfpresentation in social media, in this case based on the fact that experience self-congruity influences tourists' use of social networks during and after their trips.

In addition, it was indicated during the literature review that consumers normally present positive information about their self in social media, while filtering negative information (Gonzales and Hancock, 2011). It can be added that tourists not only filter information, but also, based on the third hypothesis of this research, they probably share more quantity of information if the experience is congruence with their self, since they use more their social networks in order to show the experience.

Finally, the present research proposed two direct relationships between perceived social value and tourists' use of social networks (hypotheses 4 and 5). It was established in the empirical model that the use of social networks influences tourists' perceived social value of the experience and, also, when tourists perceive higher social value from the experience, they tend to use more their social networks.

When it comes to hypothesis 4 , social networks can increase social value because they permit further social contact after the trip, something that tourists find socially valuable. Some authors have focused on this dimension of perceived social value (e. g. Hwang and Kim, 2015; Molz, 2013). However, the present research doesn't focus on the value of interactions between tourists. In fact, the hypothesis was based on previous sociopsychological researches. In this context, authors have analysed: social acceptance (Seidman, 2013); psychological benefits from showing the experience to others (Hudson et al., 2015); emotional support (Munar and Jacobsen, 2014); recognition (Ooi and Ek, 2010); social prestige (Kim and Jang, 2014); and impressing friends and relatives by showing their experience on the internet (Lyu, 2016) as predictors of the use of social media. In relation to this line of research, Hypothesis 4 was supported, which indicates that using social networks to show the experience increases the perception of tourists that it helped them to feel acceptable, to create good impressions and to find social approval (see measurement of social value in table 4).

Regarding hypothesis 5, some authors proposed that people are concerned about reactions of others as reference groups, and thus, when they perceived that some event provides them social value, they will probably talk about it (Kim and Tussyadiah, 2013) and they might use the internet in order to do it (Okazaki and Hiroze, 2009; Luo and Zhong, 2015). Once again, this relationship could be established based on the importance of interaction between tourists, since they may want to keep in touch with people they met during their trip, if they valued the interaction positively (Nusair, Bilgihan and Okumus, 2013; Rihova et al., 2015). However, this hypothesis was based on the fact that variables as social acceptance and social approval, as well as the good impression that tourists think the experience makes on others, will motivate them to show it more, for example by showing pictures or souvenirs (Boley, Magnini and Tuten, 2013), or more practically nowadays, by using social networks (Ayeh, Au and Law, 2013). Hence, as shown in the results and according to the affirmations by Gyimothy (2013), tourists will use more social sites if they perceive the experience provides them social value.

\section{Conclusions}

This research focuses on the analysis of experience self-congruity (an important construct related to symbolic consumption), 
perceived social value and the use of digital social networks. Based on the results, it can be established that experience self-congruity influences perceived social value, and these constructs affect the use of social networks by tourists during and after their trips. In addition, perceived social value, a consequence of experience self-congruity, affects revisit intention.

Therefore, the offer of current tourism companies must enable the perception of congruency between the experience and the tourists' self-concept. This will lead to consumers perceiving higher social value, which will positively influence the intention to return in the future. Furthermore, it has been proven that tourists feel the need to show their consumption during their vacation to others when it is congruent with their self, and they might do it currently using tools and resources that permits them to materialize something as intangible as a tourism experience, for example, the possibilities provided by social sites.

By using digital social networks, tourists can show pictures, videos, sounds, they can write what they felt, respond to commentaries of relatives and friends, share emotions with them, etc., and in doing so, they can perceive more social value from their experience. That's why tourism companies should facilitate the access to resources that help their customers in materialising the experience. For example, in some theatres or museums in which making pictures is not permitted, it might be possible that consumers wish to show what they saw, but they can't because they don't have the resources to recreate the experience on the internet, and then, they may perceive less value from the experience.

Also, it is very important to improve the relationship between clients who live the same experience. As examine during the literature review, this might be especially important when tourists visit a place or participate in an event where they perceive common interests. In these situations, tourists will probably share ideas, a lifestyle and even an identity. If the company achieves to create an environment that influences self-congruity of different tourists at the same time, in a place where clients can share emotions with each other, this could improve the existing use of social networks, the value of the tourism experience and the revisit intention.

\section{Limitations and future line of research}

This research has some limitations mainly related with the selected participants, since a convenience sampling was performed and it was circumscribed to students in the city of Valencia. These limitations make it difficult to extrapolate the results to every tourism experience or every kind of tourist. Therefore, it would be interesting to observe the results obtained from the approach of this research applied to different profiles of people surveyed, in different situations, for example, tourists surveyed during their holidays.

Another limitation refers to the fact that the respondents of this survey where students, which limited the analysis of the results based on socio-demographic characteristics of the sample, since they share country of origin, age and level of education. It would be interesting to perform this kind of investigation including differences between consumers based on their socio-demographic characteristics.

Finally, this research took into consideration a series of constructs in order to link selfcongruity and digital social networks with perceived social value and revisit intention. However, it would be interesting to include variables such as satisfaction, perceived quality, word of mouth, or consumer's loyalty, increasing the knowledge of self-congruity and social media in the area of tourism.

\section{References}

Aaker, J. L. (1997). Dimensions of brand personality. Journal of Marketing Research, 36, 346-156.

Aguirre-Rodríguez, A., Bonsjnak, M., \& Sirgy, M. J. (2012). Moderators of the selfcongruity effect on consumer decisionmaking: A meta-analysis. Journal of Business Research, 65, 1179-1188.

Ahn T, Ekinci Y, \& Li G. (2011). Self and Functional Congruence and Tourist Destination Choice. Journal of Business Research, 66(6), 719-723. 
Amaldoss, W., \& Jain, S. (2005). Pricing Of Conspicuous Goods: A Competitive Analysis of Social Effects. Journal of Marketing Research, 42, 30-42.

Amaro, S., Duarte, P., \& Henriques, C. (2016). Travelers' use of social media: A clustering approach. Annals of Tourism Research, 59, $1-15$.

Anderson, J. C., Gerbing, D. W. (1988). Structural equation modelling in practice: $A$ review and recommended two-step approach. Psychological Bulletin, 103, 411-423.

Arocena, M. \& Buffa, C. (2012). Herramientas para un abordaje simbólico cultural. Congreso de Periodismo y Medios de Comunicación, La Plata, Argentina, mayo, 2012.

Ayeh, J. K., Au, N., \& Law, R. (2013). Predicting the intention to use consumergenerated media for travel planning. Tourism Management, 35, 132-143.

Azevedo A., \& Farhangmehr, M (2005). Clothing Branding Strategies: Influence of Brand personality on advertising response. Journal of Textile and Apparel Technology and Management, 4 (3), 1-13.

Bagozzi, R.P., \& Yi, Y. (1988). On the evaluation of structural equation models. Journal of the Academy of Marketing Science, 16(1), 74-94.

Bagwell, L., \& Bernheim D. B. (1996). Veblen Effects in a Theory of Conspicuous Consumption. American Economic Review, 86(3), 349-73.

Ballesteros, E., \& Ramíres, M. (2007). Identity and community-Reflections on the development of mining heritage tourism in Southern Spain. Tourism Management, 28, 677-687.

Baloglu, S., \& Love, C. (2005). Association meeting planners' perceptions and intentions for five major US convention cities: the structured and unstructured images. Tourism Management, 26, 743-752.

Banyai, M., \& Potwarka, L. (2012) Assessing destination images of an Olympic host city using social media. European Journal of Tourism Research, 5(1), 6-18.

Barone, M., Shimp, T., \& Sprott, D. E. (1999). Product Ownership as a Moderator of SelfCongruity Effects. Marketing Letters, 10 (1), 75-85.
Beerli, A., Díaz, G., \& Moreno, S. (2007). Selfcongruity and destination choice. Annals of Tourism Research, 34(3), 571-587.

Belk, R. W. (1984). Three scales to measure constructs related to materialism: reliability, validity, and relationships to measures of happiness. Advances in Consumer Research, 11, 291-297.

Blom, T., Nilsson, M., \& Santos, X. (2016). The way to Santiago beyond Santiago. Fisterra and the pilgrimage's post-secular meaning. European Journal of Tourism Research, 12, 133-146.

Boley, B. B., Magnini, V. P., \& Tuten, T. L. (2013). Social media picture posting and souvenir purchasing behavior: Some initial findings. Tourism Management, 37, 27-30.

Bond, N., \& Falk, J. (2013). Tourism and identity-related motivations: why am I here (and not there)? International Journal of Tourism Research, 15, 430-422.

Bosnjak, M., Sirgy, M. J., Hellriegel, S., \& Maurer, O. (2011). Postvisit Destination Loyalty Judgments: Developing and Testing a Comprehensive Congruity Model. Journal of Travel Research, 50(5), 496-508.

Boo, S, Busser J, \& Baloglu S. (2009). A model of customer-based brand equity and its application to multiple destinations. Tourism Management, 30(2), 219-231.

Cabiddu, F., De Carlo, M., \& Piccoli, G. (2014). Social media affordances: Enabling customer engagement. Annals of Tourism Research, 48, 175-192.

Cantallops, A.S., \& Salvi, F. (2014). New consumer behavior: a review of research on eWOM and hotels. International Journal of Hospitality Management, 36(1), 41-51.

Chatzidakis, A., \& Lee, M. (2013). AntiConsumption as the Study of Reasons against. Journal of Macromarketing, 33(3), 189-204.

Chaudhuri, H. R., \& Majumdar, S. (2006). Of Diamonds and Desires: Understanding Conspicuous Consumption from a Contemporary Marketing Perspective. Academy of Marketing Science Review, 1.

Chebat, J. C., Sirgy, M. J., \& St-James, V. (2006). Upscale image transfer from malls to stores: A self-image congruence explanation. Journal of Business Research, 59, 1288-1296. 
Chen, C. F., Leask, A. \& Phou, S. (2016) Symbolic, Experiential and Functional Consumptions of Heritage Tourism Destinations: The Case of Angkor World Heritage Site, Cambodia. International Journal of Tourism Research, DOI: 10.1002/jtr.2077.

Cheung, C. M., \& Thadani, D. R. (2012). The impact of electronic Word-Of-Mouth communication: a literature analysis and integrative model. Decision Support Systems, 54(1), 461-470.

Chew, E. Y. T., \& Jahari, S. A. (2014). Destination image as a mediator between perceived risks and revisit intention: A case of post-disaster Japan. Tourism Management, 40, 382-393.

Cho, E., \& Kim, Y. K. (2012). The Effects of Website Designs, Self-Congruity, and Flow on Behavioral Intention. International Journal of Design, 6(2), 31-41.

Chon, K. (1992). Self-Image/destination-image congruity. Annals of Tourism Research, 19, 360-363.

Chung, N., \& Koo, C. (2012). Knowledge sharing in social networking sites for ecollaboration: Identity and bond theory perspective. In The eighteenth Americas conference on information systems, Seattle, Washington, August 9-12.

Clammer, J. (1992). Aesthetics of the self: Shopping and social being in contemporary urban Japan. En R. Shields (Ed.), Lifestyle Shopping: The Subject of Consumption (195-215), London, Routledge.

Cobasky, J. (2016). Social media opinion sharing: beyond volume. Journal of Consumer Marketing, 33(3), 172-181.

Colás, P., González, T., \& De Pablos, J. (2013). Juventud y redes sociales: Motivaciones y usos preferentes. Comunicar, 40(20), 5-24.

Corneo, G., \& Olivier, J. (1997). Conspicuous Consumption, Snobbism and Conformism. Journal of Public Economics, 66, 55-71.

Correia, A., Kozak, M., \& Reis, H. (2014). Conspicuous Consumption of the Elite: Social and Self-Congruity in Tourism Choices. Journal of Travel Research, 18, 113.

Csikszentmihalyi, M., \& Rochberg-Halton, E. (1981). The Meaning of Things: Domestic
Symbols and the Self. Cambridge: Cambridge University Press.

Cueto, J. (1981). La sociedad de consume de masas. Madrid: Salvat.

Dawson, S. (1988). Trait Materialism: Improved Measures and an Extension to Multiple Domains of Life Satisfaction. AMA Winter Educators' Conference Proceedings, Chicago: American Marketing Association, 478-481.

Dawson, S., \& Bamossy G. (1991). If We Are What We Have, What Are We When We Don't Have? Journal of Social Behavior and Personality, 6, 363-384.

Dittmar, H. (1992). Perceived Material Wealth and First Impressions. British Journal of Social Psychology, 31, 379-391.

Doran, R., Larsen, S., \& Wolf, K. (2015). Different but Similar: Social Comparison of Travel Motives Among Tourists. International Journal of Tourism Research, 17, 555-563.

Edson, J. E., \& Bettman, J. R. (2005). Self-Construal, Reference Groups, and Brand Meaning. Journal of Consumer Research, 32(3), 378-389. DOI: 10.1.1.108.5210.

Ekinci, Y., Sirakaya, E., \& Baloglu, S. (2007). Host image and destination personality. Tourism Analysis, 12, 433-446.

Ekinci, Y., Sirakaya, E., \& Preciado, S. (2013). Symbolic consumption of tourism destination brands. Journal of Business Research, 66(6), 711-718. DOI:10.1016/j.jbusres.2011.09.008.

Ellison, N. B., Steinfield, C., \& Lampe, C. (2007). The benefits of Facebook friends: social capital and college students' use of online social network. Journal of ComputerMediated Communication, 12(4), 1143$1168 . \quad$ DOI: $\quad 10.1111 / \mathrm{j} .1083-$ 6101.2007.00367.x/full.

Ericksen, M. K., \& Sirgy, M. J. (1992). Employed females' clothing preference, selfimage congruence, and career anchorage. Journal of Applied Social Psychology, 22, 408-422.

Fenollar, P., \& Ruíz, S. (2006). La posesión de productos con significado social para el consumidor. Determinantes internos y externos. Revista Española de Investigación de Marketing, 10(2), 7 - 24. 
Flügel, J. C. (1930). The psychology of clothes. London: London Press.

Fornell, C., \& Larcker, D. (1981). Evaluating structural equations models with unobservable variables and measurement error. Journal of Marketing Research, 18, 39-50.

Fournier, S. (1998). Consumers and Their Brands: Developing Relationship Theory in Consumer Research. Journal of Consumer Research, 24(4), 343-73. DOI: 10.1086/209515

Gazley, A., \& Waitling, L. (2015). Me, my tourist-self, and I: the symbolic consumption of travel. Journal of Travel \& Tourism Marketing, 32(6), 1-17.

Ger, G., \& Belk, R.W. (1996). Cross-cultural differences in materialism. Journal of Economic Psychology, 17, 55-77. DOI: 10.1016/0167-4870(95)00035-6.

Giddens, A. (1991). Modernity and SelfIdentity. Stanford: Stanford University Press.

Gonzales, A. L., \& Hancock, J. T. (2011). Mirror, Mirror on my Facebook Wall: Effects of Exposure to Facebook on Self-Esteem. Cyberpsychology, behavior, and social networking, 14(1), 79-86.

Graeff, R. (1996). Image congruence effects on product evaluation: the role of self monitoring and public/private consumption. Psychology \& Marketing, 3, 481-99.

Grier, S. A., \& Deshpande, R. (2001). Social Dimensions of Consumer Distinctiveness: The Influence of Group Social Status and Identity on Advertising Persuasion. Journal of Marketing Research, 38(2), 216-224. DOI: $\quad$ http://dx.doi.org/10.1509/jmkr.38.2. 216.18843.

Grubb, E. L., \& Grathwohl, H. L. (1967). Consumer Self-Concept, Symbolism and Market Behavior: A theoretical Approach. Journal of Marketing, 31, 22-27.

Gupta, D., \& Ahmad, Z. (2014). Mutations and transformations: the contested discourses in contemporary cultural tourism. International Journal of Hospitality \& Tourism Systems, 7(1), 59-70.

Gyimothy, S. (2013). Symbolic convergence and tourism social media. In Tourism Social Media: Transformations in Identity, Community and Culture. Tourism Social Science Series, 18, 55-71.
Hatcher, L. (1994). A Step by Step Approach to Using the SAS System for Factor Analysis and Structural Equation Modeling, SAS Institute Inc, Cary.

Heath, A.P., \& Scott, D. (1998). The selfconcept and image congruence hypothesis: an empirical evaluation in the motor vehicle market. European Journal of Marketing, 32, 1110-1123.

Hosany, S., \& Martin, D. (2012). Self-image congruence in consumer behavior. Journal of Business Research, 65, 685-691.

Hudson, S; Roth, M; Madden, T; Hudson, R. (2015). The effects of social media on emotions, brand relationship quality, and word of mouth: An empirical study of music festival attendees. Tourism Management, $47, . .68-76$.

Hung, K., \& Petrick, J. F. (2012). Testing the effects of congruity, travel constraints, and self-efficacy on travel intentions: An alternative decision-making model. Tourism Management, 33, 855-867.

Hwang, H., \& Kim, K. O. (2015). Social media as a tool for social movements: the effect of social media use and social capital on intention to participate in social movements. International Journal of Consumer Studies, $39,478-488$.

Ibrahim, H., \& Najjar, F. (2008). Assessing the effects of self-congruity, attitudes and customer satisfaction on customer behavioural intentions in retail environment. Marketing Intelligence \& Planning, 26(2), 207-227.

Johar, S., \& Sirgy, M. J. (1999). Toward an Integrated Model of Self-Congruity and Functional Congruity. European Advances in Consumer Research, 4, 252-256.

Jamal, A., \& Goode, M. (2001). Consumers and brands: a study of the impact of selfimage congruence on brand preference and satisfaction. Marketing Intelligence \& Planning, 19, 482-493.

James, W. (1890). Principles of Psychology. New York: Holt.

Jones, M. A., Mothersbaugh, D. L., \& Beatty D. (2000). Switching Barriers and Repurchase Intention In Services. Journal of Retailing, $75(2), \quad 259-274 . \quad$ DOI:10.1016/S00224359(00)00024-5.

Kang, J. H. (2002). A structural model of image-based and utilitarian decision-making 
processes for participant sport consumption. Journal of Sport Management, 16, 173-89.

Kastanakis, M. N., \& Balabanis, G. (2012). Between the mass and the class: antecedents of bandwagon luxury consumption behavior. Journal of Business Research, 64(10), 1399-1407. DOI:10.1016/j.jbusres.2011.10.005.

Kastenholz, E. (2004). Assessment and Role of Destination-Self-Congruity. Annals of Tourism Research, 31(3), 719-723.

Kerr, G., Lewis, C., \& Burgess, L. (2012). Bragging Rights and Destination Marketing: A Tourism Bragging Rights Model. Journal of Hospitality and Tourism Management, 19, 1-8.

Kim, D., \& Jang, S. (2014). Symbolic Consumption in Upscale Cafés: Examining Korean Gen Y Consumers' Materialism, Conformity, Conspicuous Tendencies and Functional Qualities. Journal of Hospitality \& Tourism Research, 38, 39-47. DOI: 10.963.4801.4525.633.

Kim, J. J., \& Tussyadiah, I.P. (2013). Social networking and social support in tourism experience: the moderating role of selfpresentation strategies. Journal of Travel and Tourism Marketing, 30(1), 78-92. DOI: 10.1080/10548408.2013.751220.

Kim, M. J., Lee, C. K., \& Bonn, M. (2015). The effect of social capital and altruism on seniors' revisit intention to social network sites for tourism-related purposes. Tourism Management, 53, 96-107.

Kim, S. (2012). The Production and Consumption of Experience: Inter-Asian Responses to Small Screen Tourism in Korea. Doctoral dissertation summary. European Journal of Tourism Research, 5(1), 76-79.

Kim, S., \& Jun, J. (2016). The impact of event advertising on attitudes and visit intentions. Journal of Hospitality and Tourism Management, 29, 1-8.

Kirillova, K., Xinran, Y. L., \& Cai, L. (2016). Existential Authenticity and Anxiety as Outcomes: The Tourist in the Experience Economy. International Journal of Tourism Research, DOI: 10.1002/jtr.2080.

Kleijnen, M., de Ruyter, K., \& Andreassen, T.W. (2005). Image congruence and the adoption of service innovations. Journal of Service Research, 7(4), 343-59.
Kressmann, F., Sirghy, M. J., Herrmann, A., Huber, F., Huber, S., \& Lee, D. J. (2006). Journal of Business Research, 59, 955-964.

Kumar, V., \& Nayak, J. K. (2014). The role of self-congruity and functional congruity in influencing tourists' post visit behaviour. Advances in Hospitality and Tourism Research, 2(2), 24-44.

Kwak, D. H., \& Kang, J. H. (2009). Symbolic purchase in sport: the roles of self-image congruence and perceived quality. Management Decision, 47(1), 85-99.

La Barbera, P., \& Gurhan Z. (1997). The Role of Materialism, Religiosity, and Demographics in Subjective Well-Being. Psychology and Marketing, 14, 71-97.

Ladhari, R., \& Michaud, M. (2015). eWOM Effects on hotel booking intentions, attitudes, trust, and website perceptions. International Journal of Hospitality Management, 46(1), 36-45.

Landon, L. E. (1974). Self Concept, Ideal Self Concept, and Consumer Purchase Intentions. Journal of Consumer Research, 1(2), 44-51. DOI: 10.1086/208590.

Lee, E. J. (2013). A prototype of multicomponent brand personality structure: a consumption symbolism approach. Marketing \& Psychology, 30(2), 173-186. DOI: 10.1002/mar.20596.

Lenhart, A., \& Fox, S. (2006). A portrait of the internet's new storytellers. Pew internet \& American life project, 16(15), 1-24.

Lenton A, Slabu L, Sedikides C, Power K. (2013). I feel good, therefore I am real: testing the causal influence of mood on state authenticity. Cognition and Emotion, 27(7), 1202-1224.

Levy, S. J. (1959). Symbols for Sale. Harvard Business Review, 37, 117-124.

Lin, Y., Pearson, T., \& Cai, L. (2011). Food as a form of destination identity: A tourism destination brand perspective. Tourism and Hospitality Research, 11(1), 30-48.

Lipscomb, T. J. (1988). Indicators of materialism in children's free speech: age and gender comparison. The Journal of Consumer Marketing, 5(4), 41-46. DOI: 10.1108/eb008237.

Litvin, S. W., \& Goh, H. K. (2002). Self-image congruity: a valid tourism theory. Tourism Management, 23, 81-83. 
Liu, C. R., Lin, W. R., \& Wang, Y. C. (2012)

Relationship between self-congruity and destination loyalty: Differences between first-time and repeat visitors. Journal of Destination Marketing \& Management, 1, 118-123.

Lorenzi, C. F. (1991). Self-stereotyping and self-enhancement in gender groups. European Journal of Social Psychology, 21, 403-417. DOI: 10.1002/ejsp.2420210504.

Luo, Q; Zhong, D. (2015). Using social network analysis to explain communication characteristics of travel-related electronic word-of-mouth on social networking sites. Tourism Management, 46, 274-282.

Lyu, S. O. (2016). Travel selfies on social media as objectified self-presentation. Tourism Management, 54, 185-195.

Maldonado, C. (2012). Narrativa hiper textual Mapuche: reconstrucción contra hegemónica del archive Mnémico. Perspectivas de la Comunicación, 5(1), 1727.

Malhotra, N. K. (1988). Self concept and product choice: an integrated perspective. Journal of Economic Psychology, 9, 1-28.

Manago, A. M., Graham, M. B., Greenfield, P. M., \& Salimkham, G. (2009). Selfpresentation and gender on MySpace. Journal of Applied Developmental Psychology, 29, 446-458.

Martín, S. M. (1982). La influencia social de la televisión. Revista española de investigación sociológica, 17(82), 65-82.

Martín M., \& Torres, M. (2013). Medios Masivos, Nuevas Tecnologías y modos de estar juntos: Puntos de entrada al consume simbólico en la vida cotidiana. Question, 1(31), 3-12.

Matzler, K., Strobl, A., Stokburgher-Sauer, N., Bobovnicky, A, \& Bauer, F. (2016). Brand personality and culture: The role of cultural differences on the impact of brand personality perceptions on tourists' visit intentions. Tourism Management, 52, 507520.

Mazodier, M., \& Merunka, D. (2012). Achieving brand loyalty through sponsorship: the role of fit and self-congruity. Journal of the Academy of Marketing Science, 40, 807843.

McCracken, G. (1987). The History of Consumption: A Literature Review, and
Consumer Guide. Journal of Consumer Policy, 10, 139-166. DOI: 10.1007/BF00411633.

Molz, J. G. (2013). Social networking technologies and the moral economy of alternative tourism: the case of couchsurfing.org. Annals of Tourism Research, 43, 210-230.

Munar, A. M., \& Jacobsen, J. K. S. (2014). Motivations for sharing tourism experiences through social media. Tourism Management, 43, 46-54.

Murphy, L., Moscardo, G., \& Benckendorff, P. (2007). Using Brand Personality to Differentiate Regional Tourism Destinations. Journal of Travel Research, 45(1), 5-14.

Nadkarni, A., \& Hofmann, S. G. (2012). Why do people use Facebook? Personality and Individual Differences, 52, 243-249.

Nam J, Ekinci Y, \& Whyatt G. (2011). Brand Equity, Brand Loyalty and Consumer Satisfaction. Annals of Tourism Research, 38(3), 1009-1030.

Naredo, J. M. (1981). El fetichismo del consumo. Transición, 28, 17-22.

Nunnally, J. C., \& Bernstein, I. H. (1994). Psychometric Theory ( $3^{a}$ edición), McGrawHill, New York.

Nusair, K. K., Bilgihan, A., \& Okumus, F. (2013). The Role of Online Social Network Travel Websites in Creating Social Interaction for Gen $Y$ Travelers. International journal of tourism research, 15, 458-472.

Okazaki, S., \& Hirose, M. (2009). Does gender affect media choice in travel information search? On the use of mobile Internet. Tourism Management, 30, 794-804.

Ooi, C. S., \& Ek, R. (2010). Culture, work and emotion. Culture Unbound: Journal of Current Cultural Research, 2, 303-310.

Park, C. W., Deborah J. M., Priester, J., Eisingerich, A., \& lacobucci, D. (2010). Brand Attachment and Brand Attitude Strength: Conceptual and Empirical Differentiation of Two Critical Brand Equity Drivers. Journal of Marketing, 74(6), 1-17. DOI: 10.1509/jmkg.74.6.1.

Poddar, A., Donthu, N., \& Wei, Y. (2009). Web site customer orientations, web site quality, and purchase intentions: The role of web site personality. Journal of Business Research, 62(4), 441-450. 
Qu, Y., \& Qu, H. (2015). Nonutilitarian Tourism Destination Positioning: A Case Study in China. International Journal of Tourism Research, 17, 388-398.

Quester, P. G., Karunaratna, A., \& Goh, L. K., (2000). Self-congruity and Product Evaluation: A Cross-Cultural Study. Journal of Consumer Marketing, 17(6), 525-537.

Randle, M., \& Dolnicar, S. (2011). Selfcongruity and volunteering: a multiorganisation comparison. European Journal of Marketing, 45(5), 739-758.

Ren, Y., Harper, F. M., Drenner, S., Terveen, L., Kiesler, S., \& Riedl, J. (2012). Building member attachment in online communities: applying theories of group identity and interpersonal bonds. MIS Quarterly, 36(3), 841-864.

Ren, Y., Kraut, R., \& Kiesler, S. (2007). Applying common identity and bond theory to design of online communities. Organization Studies, 28(3), 377-408.

Richins M. L., \& Dawson, S. (1990). Measuring material values: a preliminary report of scale development. Advances in Consumer Research, 7, 169-175.

Richins M. L., \& Dawson, S. (1992). A Consumer Values Orientation for Materialism and Its Measurement: Scale Development and Validation. The Journal of Consumer Research, 19(3), 303-316. DOI: 10.1086/209304.

Richins, M. L., McKeage, K. R., \& Najjar, D. (1992). An exploration of materialism and consumption-related affect. Advances in Consumer Research, 19, 229-236.

Richins, M. L. (1994a). Valuing Things: The Public and Private Meanings of Possessions. Journal of Consumer Research, 21(4), 504-521. DOI: 10.1086/209414.

Richins, M. L. (1994b). Special Possessions and the Expression of Material Values. Journal of Consumer Research, 21(3), 522533. DOI: $10.1086 / 209415$.

Rihova, I.; Buhalis, D.; Moital, M.; Gouthro, M. B. (2015). Conceptualising Customer-tocustomer Value Co-creation in Tourism. International Journal of Tourism Research, 17, 356-363.

Rosenberg, M. (1965). Society and the Adolescent Self-Image. Princeton, NJ: Princeton University Press.
Sangkhawasi, T., \& Johri M. (2007). Impact of Status Brand Strategy on Materialism in Thailand, Journal of Consumer Marketing. 24(5), 275-82. DOI: $10.1108 / 07363760710773094$.

Schroeder, J., \& Dugal S. (1995). Psychological Correlates of the Materialism Construct. Journal of Social Behavior and Personality, 10(1), 243-253.

Seidman, G. (2013). Self-presentation and belonging on Facebook: How personality influences social media use and motivations. Personality and Individual Differences, 54, 402-407.

Serra, D. (2013). Entorno virtual y turismo: interacción simbólica. Revista Iberoamericana de Turismo, 3(2), 17-24.

Servidio, R. (2015). Images, affective evaluation and personality traits in tourist behaviour: An exploratory study with Italian postcards. Tourism Management Perspectives, 16, 237-246.

Shanahan, M. C. (2009). Identity in science learning: exploring the attention given to agency and structure in studies of identity. Studies in Science Education, 45(1), 43-64.

Sharma, A., \& Shruti, S. (2015). Impact of Promotion on Destination Reputation: A Case of Gujarat International. Journal of Hospitality \& Tourism Systems, 8(1), 23-33.

Shimp, T. A., \& Sharma, S. (1987). Consumer Ethnocentrism: Construction and Validation of the CETSCALE. Journal of Marketing Research, 24, 280-89. DOI: $10.2307 / 3151638$.

Shrum, L. J., Wong, N., Arif, F., Chugani, S. K., Gunz, A., Lowrey, T. M., Naim, A., Pandelaere, M., Ross, S. M., Ruvio, A., Scott, K., \& Sudie, J. (2013). Reconceptualizing materialism as identity goal pursuits: functions, processes and consequences. Journal of Business Research, 66(8), 1179-1185. DOI:10.1016/j.jbusres.2012.08.010.

Sidali, K. L., Kastenholz, E., \& Bianchi, R. (2013). Food tourism, niche-markets and products in rural tourism: Combining the intimacy model and the experience economy as a rural development strategy. Journal of Sustainable Tourism, 23 (8), 1179-1197. 
Silva, C. M. (2012). Mountain destination image held by residents and tourists. European Journal of Tourism Research, 5(2), 176-181. Simmel, G. (1903). Fashion. Los Angeles: University of California Press.

Sirgy, M. J. (1982). Self-Concept in Consumer Behavior: A Critical Review. Journal of Consumer Research, 9, 287-300.

Sirgy, M. J. (1985). The self-concept in relation to product preference and purchase intention. Developments in Marketing Science, 3, 350-354.

Sirgy, M. J., Cole, D., Kosenko, R., Meadow, L., Rahtz, D., Cicic M., Jin, G., Yarsuvat, D., Blenkhorn, D., \& Nagpal, N. (1995). A Life Satisfaction Measure: Additional Validation Data for the Congruity of Life Satisfaction Measure. Social Indicators Research, 34, 237-259.

Sirgy, M. J., Grewal, D., Mangleburg, T., Park, J., Chon, K., Claiborne, C. B., Johar, J., \& Berkman, H. (1997). Assessing the Predictive Validity of Two Methods of Measuring Self-Congruity. Journal of the Academy of Marketing Science, 25, 229241.

Sirgy, M. J., Grewal, D., Mangleburg, T. (2000). Retail Environment, Self-Congruity, and Retail Patronage: An Integrative Model and a Research Agenda. Journal of Business Research, 49, 127-138.

Sirgy, M. J., Lee, D.-J., Johar, J. S., \& Tidwell, J. (2008). Effect of self-congruity with sponsorship on brand loyalty. Journal of Business Research, 61(10), 1091-1097.

Souza, A. G. (2015). Hysteresis, Cultural Dimensions and the Image of the Sustainability of Tourism Destinations: A Cross-Cultural Comparative Study between Brazil and the Netherlands. European Journal of Tourism Research, 11, 176-180.

Sparks, B., Bradley, G., \& Jennings, G. (2011). Consumer value and self-image congruency at different stages of timeshare ownership. Tourism Management, 32, 1176-1185.

Stokowski, P. A. (2011). The Smile Index: Symbolizing People and Place in Colorado's Casino Gaming Towns. Tourism Geographies, 13(1), 21-44.
Sun, X., Wang, P., Lepp, A., \& Robertson, L. (2014). Symbolic Consumption and Brand Choice: China's Youth Hostels for the International Travel Market. Journal of China Tourism Research, 10(1), 51-68. DOI: 10.1080/19388160.2013.870950.

Tussyadiah, L. P.; Kausar, D. R., \& Soesilo (2015). The Effect of Engagement in Online Social Network on Susceptibility to influence. Journal of Hospitality \& Tourism Research, 1-23 DOI: $10.1177 / 1096348015584441$.

Uchiyama, Y., \& Kohsaka, R. (2016). Cognitive value of tourism resources and their relationship with accessibility: A case of Noto region, Japan. Tourism Management Perspectives, 19, 61-68.

Usakli, A., \& Baloglu, S. (2011). Brand personality of tourist destinations: An application of self-congruity theory. Tourism Management, 32, 114-127.

Wang, S. (2016). Roles of place identity distinctiveness and continuity on resident attitude toward tourism. European Journal of Tourism Research, 13, 58-68.

White, N., \& White, P. (2009). The comfort of strangers: tourists in the Australian Outback. International Journal of Tourism Research, 11, 143-153.

Xiang, Z., \& Gretzel, U. (2010). Role of social media in online travel information search. Tourism Management, 31, 179-188.

Yim, C. K., Chan, K. W., \& Hung, K. (2007). Multiple reference effects in service evaluations: Roles of alternative attractiveness and self-image congruity. Journal of Retailing, 83(1), 147-157.

Yuksel, A., Yuksel, F., \& Bilim, Y. (2010). Destination attachment: Effects on customer satisfaction and cognitive, affective and conative loyalty. Tourism Management, 31, 274-284.

Zeng, B; Gerritsen, R. (2014). What do we know about social media in tourism? A review. Tourism Management Perspectives, 10, 27-36. 